\title{
PENGARUH KELEBIHAN PENGHASILAN DAN RELIGIUSITAS TERHADAP INTENSI MASYARAKAT DESA TAKERANKLATING TIKUNG LAMONGAN UNTUK MENJADI NASABAH DI PERBANKAN SYARIAH
}

\author{
Dian Mariana Lestari \\ Universitas Islam Lamongan \\ e-mail: dianmlestarimzh@gmail.com
}

\begin{abstract}
Sharia bank is a bank which operated by al-Quran and Hadist principle. Completed with MUI intructions therefore when operational process not rely on tire tread. However almost people have a salary and religious background look of that things people sould be make their insentrum to choose sharia bank as a main priority to be the customer. This skripsi entitled "The influence of salary strength and the religiousity toward the intention of Takeranklating people to be the customer in sharia bank". This research using quantitative method so answer the research problem about how many the influence of salary strength, and the religiousity in a parsial manner and simultaneous toward people intention in Takeranklating village to be the customer in sharia Bank. This research used quantitative methods with explanation design. This research collect the data used quitionnare and documentation. While data analyze technique used double regression test using parsial and simultaneous test. Result of research showed that the variabel of salary strenght get the positive influence and significant toward people intention of Takeranklating to be a customer in sharia bank with regression coeficient 0,022 scores, score t test is 2,150 scores and the significant is 0,038 scores. While the variabel of religiousity get positive influence and significant toward people intention of Takeranklating to be a customer in sharia bank with regression coefficient 0,622 score, the score of $t$ test is 75,635 scores, and the significant score is 0,000,. While the salary strength and religiousity in a simultaneous manner is significant influence toward people intention of Takeranklating village to be a customer in sharia bank with $f$ test is 2906,753 scores, the significant score is 0,000 scores and f table is 3,10 scores.
\end{abstract}

Keywords: Salary Strength, Religiousity, People Intention

\section{Pendahuluan}

Perbankan syariah di masyarakat masih menjadi sebuah hal yang bisa dikatakan asing, meskipun bank syariah sudah mulai berdiri setelah ada undang-undang No. 7 tahun 1992 dan undang-undang tersebut direvisi menjadi undang-undang perbankan No. 10 tahun 1998 yang dikemas dalam bentuk sebuah bank yang menjalankan usahanya dengan sistem bagi hasil. Bank syariah merupakan bank yang beroperasi dengan tidak mengandalkan pada bunga. Bank Islam adalah lembaga keuangan atau perbankan yang beroperasional dan produknya dikembangkan berlandasan pada al-Quran dan Hadist Nabi SAW. ${ }^{1}$ Perbankan syariah dilengkapi dengan prinsip yang bersumber dari al-Quran dan Hadist Nabi SAW ditambah

\footnotetext{
${ }^{1}$ Muhammad, Manajemen Bank Syariah (Yogyakarta: STIM YKPN, 2011), 15.
} 
dengan fatwa-fatwa ulama dalam hal ini Majelis Ulama Indonesia (MUI) menjadikan perbankan syariah semakin gencar mempromosikan produk-produk yang dimilikinya.

Dewasa ini, hampir semua masyarakat memiliki penghasilan sendiri-sendiri, tetapi tidak bisa dipungkiri bahwa penghasilan yang diperoleh tentu berbeda-beda. Artinya tinggi rendahnya penghasilan seseorang ditentukan oleh usaha yang dilakukannya. Kelebihan penghasilan yang dimiliki oleh masyarakat seharusnya menjadikan keinginannya semakin kuat dan menjadikannya untuk menjadi nasabah di perbankan. Menjadi nasabah di perbankan harus berdasarkan perencanaan yang mendasar. Artinya intensi masyarakat untuk menjadi nasabah sebelum memutuskan menjadi nasabah dipengaruhi oleh beberapa hal mendasar.

Penghasilan yang dimaksudkan ialah jumlah dari konsumsi dan tabungan, dengan kata lain bahwa penghasilan itu merupakan bentuk imbalan atau balas jasa yang diperoleh seseorang setelah melakukan sebuah pekerjaan yang dalam bentuk upah, gaji, bagi hasil, sewa dan lain-lain. Sementara religiusitas merupakan seberapa jauh pengetahuan, seberapa kokoh keyakinan, seberapa pelaksanaan ibadah dan akidah, dan seberapa dalam penghayatan atas agama yang dianut. ${ }^{2}$

Bahkan akhir-akhir ini, perbankan syariah menjadi perbincangan hangat di seminarseminar, workshop-workshop, media cetak dan media elektronik. Hal ini menjadikan perbankan syariah tidak asing lagi bagi semua lapisan masyarakat. Di samping itu, rata-rata masyarakat memeluk agama Islam yang bisa dikatakan rata-rata memahami perbuatan mana yang halal dan perbuatan mana yang haram. Melihat fenomena tersebut seharusnya seseorang atau masyarakat menjadikan perbankan syariah sebagai prioritas utama dalam memilih untuk menjadi nasabah. Adanya penghasilan masyarakat ditambah dengan latar belakang agama yang dianut akan menjadikan intensi masyarakat memilih perbankan syariah sebagai prioritas utama untuk menjadi nasabah.

Begitu halnya dengan masyarakat Desa Takeranklating, semua masyarakat memiliki penghasilannya sendiri-sendiri dari profesinya masing-masing. Berdasarkan dari jumlah masyarakat berdasarkan jenis pekerjaannya yang berbeda-beda yang bergantung pada sumber penghasilannya ada yang lebih dan ada yang kurang. Sehingga dengan kelebihan penghasilan yang dimiliki mereka menggunakan untuk menabung dan lain sebagainya.

Di samping itu, hampir semua masyarakat Desa Takeranklating memeluk agama Islam sebagai keyakinan dalam beragama. Dengan demikian maka semakin tinggi tingkat religiusitas masyarakat Desa Takeranklating, semakin tinggi pula kesadarannya untuk menggunakan kelebihan penghasilannya untuk menjadi nasabah di perbankan syariah. Namun tidak bisa dipungkiri juga masih terdapat masyarakat yang memilih untuk menyimpan uangnya sendiri di rumahnya masing-masing. Pilihan tersebut bukan tanpa dasar dilakukan melainkan terdapat alasan, mulai dari penghasilannya masih bisa disimpan sendiri, menganggap sama antara perbankan syariah dengan perbankan konvensional, sulitnya akses, malas mengganti bank, dan kurangnya pengetahuan terhadap perbankan syariah. Fokus penelitian ini adalah tentang seberapa besar pengaruh kelebihan penghasilan dan religiusitas secara parsial terhadap intensi masyarakat Takeranklating untuk menjadi nasabah di perbankan syariah, dan seberapa besar pengaruh kelebihan penghasilan dan religiusitas secara

\footnotetext{
${ }^{2}$ Iredho Fani Reza, "Hubungan Antara Religiusitas dengan Moralitas pada Remaja di Madrasah Aliyah (MA)" dalam Jurnal Humanitis, Vol. X, No. 2, Agustus 2013, 49.
} 
bersama-sama terhadap intensi masyarakat Takeranklating untuk menjadi nasabah di perbankan syariah.

\section{Konsep Teori Perilaku Konsumen}

American Marketing Association mendefinisikan perilaku konsumen (costumer behavior) sebagai dinamika interaksi antara pengaruh dan kesadaran, perilaku, dan lingkungan di mana manusia melakukan pertukaran aspek-aspek kehidupan. Dengan kata lain perilaku melibatkan pemikiran dan perasaan yang mereka alami serta tindakan yang mereka lakukan dalam proses konsumsi. Hal itu mencakup segala hal pada lingkungan yang memengaruhi pemikiran, perasaan, dan tindakan tersebut. ${ }^{3}$

Menurut Griffin perilaku konsumen adalah semua kegiatan, tindakan, serta proses psikologi yang mendorong tindakan tersebut pada saat sebelum membeli, ketika membeli, menggunakan, menghabiskan produk dan jasa setelah melakukan hal-hal di atas atau kegiatan mengevaluasi. ${ }^{4}$ Menurut Schiffman dan Kanuk merupakan proses seseorang dalam mencari, membeli, menggunakan, mengevaluasi, dan bertindak pasca konsumsi produk, jasa maupun ide yang diharapkan bisa memenuhi kebutuhan. ${ }^{5}$

Dari beberapa pendapat, dapat disimpulkan bahwa perilaku konsumen merupakan tindakan yang dilakukan oleh seseorang atau kelompok yang langsung berhubungan dengan proses dalam pengambilan berbagai keputusan di dalam mendapatkan sampai kepada penggunaan barang atau jasa yang dipengaruhi oleh berbagai macam lingkungan.

Sedangkan keputusan pembelian konsumen dipengaruhi oleh tiga faktor, yaitu: ${ }^{6}$

1. Faktor internal (faktor pribadi)

Pengaruh faktor internal atau pribadi (presepsi, keluarga, motivasi dan keterlibatan, pengetahuan, sikap, pembelajaran, kelompok usia, dan gaya hidup).

2. Faktor eksternal

Faktor eksternal terdiri atas budaya, kelas sosial, dan keanggotaan dalam suatu kelompok.

3. Faktor situasional

Situasi dapat dipandang sebagai pengaruh yang timbul dari faktor yang khusus untuk waktu dan tempat yang spesifik yang lepas dari karakteristik konsumen dan karakteristik objek. Faktor situasional meliputi lingkungan fisik dan waktu. ${ }^{7}$

\section{Keputusan Pembelian Konsumen}

Dalam keseharian kehidupannya, konsumen selalu berbelanja apa yang ia butuhkan mulai dari komoditi yang sangat diperlukan sampai kebarang yang sebetulnya kurang diperlukan tapi dibeli juga. Keputusan membeli yang dilakukan oleh konsumen dipengaruhi

\footnotetext{
${ }^{3}$ J. Paul Peter dan Jerry C. Olson, Perilaku Konsumen dan Strategi Pemasaran (Jakarta: Salemba Empat, 2014), 6.

${ }^{4}$ Etta Mamang Sangabdji dan Sopiah, Perilaku Konsumen (Yogyakarta: Andi Offset, 2013), 8.

${ }^{5}$ Ristiyanti Prasetijo dan John J.O.I Ihalauw, Perilaku Konsumen (Yogyakarta: Andi Offset, 2009), 9.

${ }^{6}$ Etta Mamang Sangabdji dan Sopiah, Perilaku Konsumen , 4.

${ }^{7}$ Ibid, 49.
} 
oleh banyak hal. Demikian pola konsumen terbentuk karena pengaruh lingkungan baik kebudayaan, kelas sosial, keluarga, dan klub-klub. ${ }^{8}$

Kebudayaan yang dimaksud di sini sangat berpengaruh terhadap nilai-nilai dan pola perilaku seseorang anggota kebudayaan tertentu. Kebudayaan ini diwariskan dari generasi ke generasi berikutnya. Dengan demikian selera seseorang akan mengikuti pola selera yang dilakukan oleh nenek moyangnya. Kelas sosial yang dimaksudkan tadi merupakan kelompok masyarakat yang memiliki tingkatan, dari yang paling rendah sampai yang paling tinggi. ${ }^{9}$ Orang-orang dalam kelas sosial tertentu cenderung memiliki perilaku, kebiasaan tertentu dalam kebiasaan sehari-hari. Bila dikaitkan dengan intensi masyarakat untuk menjadi nasabah di perbankan syariah maka masyarakat tidak serta merta memutuskan untuk menjadi nasabah diperbankan syariah melainkan untuk memutuskan diri menjadi nasabah diperbankan syariah bergantung kepada lingkungan masing-masing.

Dalam Islam, perilaku konsumsi telah diatur dengan sedemikian rupa untuk mencapai tingkat kesehatan dan kekuatan yang berkualitas. Begitu juga halnya kehidupan yang ditopang oleh fasilitas yang baik atau bagus, akan mendatangkan perilaku hidup yang baik dan bagus pula, baik perilaku itu bersifat perilaku keagamaan maupun bersifat perilaku keduniaan. Islam sebagai pedoman hidup mengatur segenap perilaku manusia dalam memenuhi kebutuhan hidupnya. Demikian pula masalah konsumsi, Di dalam pandangan Islam, perilaku konsumsi mempunyai tujuan yang berbeda dengan tujuan perilaku konsumsi dalam pandangan ekonomi konvensional yang hanya ingin memenuhi kebutuhan jasmaniah lahiriah, melainkan di samping memenuhi kebutuhan jasmaniah lahiriah, juga memenuhi kebutuhan rohaniah batiniah. ${ }^{10}$

Islam mengatur bagaimana manusia bisa melakukan kegiatan-kegiatan konsumsi yang membawa manusia berguna bagi kemaslahatan hidupnya. Perilaku konsumsi yang sesuai dengan ketentuan Allah dan Rasulullah SAW akan menjamin kehidupan manusia yang lebih sejahtera. Kepuasan seorang muslim tidak didasarkan atas banyak sedikitnya barang yang bisa dikonsumsi, tetapi lebih dikarenakan apa yang dilakukannya sebagai ibadah dengan memenuhi apa yang diperintahkan Allah SWT dan menjauhi segala larangan Allah SWT. Tindakan-tindakan yang merugikan, seperti pemborosan, dilarang Allah. Dengan demikian kepuasan bukan didasarkan atas banyaknya barang yang dikonsumsi, tetapi didasarkan atas kemampuan fisik manusia dalam menggunakan barang yang dikonsumsinya dalam melangsungkan hidupnya.

\section{Konsep Perbankan Syariah}

Bank Islam atau selanjutnya disebut dengan bank syariah, adalah bank yang beroperasi dengan tidak mengandalkan pada bunga. Bank Islam atau biasa disebut dengan tanpa bunga, adalah lembaga keuangan atau perbankan yang beroperasional dan produknya dikembangkan berlandaskan pada al-Quran dan Hadist Nabi SAW. ${ }^{11}$ Begitu juga dengan yang diungkapkan

\footnotetext{
${ }^{8}$ Buchari Alma, Manajemen Pemasaran Dan Pemasaran Jasa (Bandung: Alfabeta, 2009), 96.

${ }^{9}$ Ristiyanti Prasetijo dan John J.O.I Ihalauw, Perilaku Konsumen, 177.

${ }^{10}$ Hunafa, "Etika Konsumsi dalam Prespektif Ekonomi Islam" dalam Jurnal Studi Islamika, Vol. 11, No. 2 (Desember, 2014), 363.

${ }^{11}$ Muhammad, Manajemen Bank Syariah (Yogyakarta: STIM YKPN, 2011), 15.
} 
oleh Khaerul Umam, bank syariah merupakan salah satu bentuk dari perbankan nasional yang mendasarkan operasionalnya pada syariat (hukum) Islam. ${ }^{12}$

Di dalam pengertian lain juga disebutkan bahwa bank Islam adalah lembaga keuangan yang usaha pokoknya memberikan pembiayaan dan jasa-jasa lainya dalam lalu lintas pembayaran serta peredaran uang yang pengoperasiannya disesuaikan dengan prinsip syariat Islam. ${ }^{13}$ Bahkan di dalam undang-undang No. 21 Tahun 2008 tentang perbankan syariah pasal 1 disebutkan bahwa perbankan syariah adalah segala sesuatu yang menyangkut bank syariah dan unit usaha syariah, mencakup kelembagaan, kegiatan usaha, serta cara dan proses dalam melaksanakan kegiatan usahanya. ${ }^{14}$

Berdasarkan beberapa pengertian yang telah peneliti kemukakan dapat ditarik sebuah kesimpulannya bahwa perbankan syariah merupakan perbankan yang melandaskan operasionalnya berdasarkan al-Quran dan Hadits sebagai pokok atau dasar hukumnya, di samping dasar hukum yang bersumber dari undang-undang yang melegalkan operasional perbankan syariah. Perbankan syariah memberikan solusi bagi masyarakat yang menganut ajaran Islam untuk menggunakan jasa yang tanpa bunga.

Adapun dasar hukum perbankan syariah di dalam menjalankan usahanya dimulai semenjak dikeluarkan pakto 1988 oleh pemerintah yang memperkenankan berdirinya bankbank baru, dari itu bank syariah mulai didirikan. Pada saat itu bank syariah belum diberikan kebebasan yang berarti. Selanjutnya posisi perbankan syariah semakin pasti setelah disahkan UU Perbankan No. 7 Tahun 1992 dimana pada saat itu bank diberikan kebebasan untuk menentukan jenis imbalan yang akan diambil dari nasabahnya baik yang berupa bunga ataupun yang berupa keuntungan-keuntungan bagi hasil. ${ }^{15}$ Selanjutnya bank syariah semakin diberikan keuntungan dengan terbitnya UU No. 10 tahun 1998 ini sekaligus pasal 6 pada PP No. 72/1992 yang melarang dual sistem. Dengan tegas pasal 6 UU No. 10 tahun 1998 membolehkan bank umum yang melakukan kegiatan secara konvensional dapat juga melakukan kegiatan usaha dengan berdasarkan prinsip syariah. ${ }^{16}$

Di dalam menjalankan usahanya bank syariah berpijakan pada peraturan Bank Indonesia dengan surat keputusan direksi Bank Indonesia antara lain 1) Undang-undang No. 10 tahun 1998, tentang perubahan atas undang-undang No. 7 tahun 1992 tentang perbankan, berikut penjelasannya; 2) Undang-undang republik Indonesia No.23 tahun 1999 tentang Bank Indonesia.

Begitu halnya, bila merujuk pada fatwa MUI No. 1 Tahun 2004 tentang bunga sebagai dasar operasional perbankan syariah antara lain pertama, pengertian bunga dan riba antara lain 1) Bunga adalah tambahan yang dikenakan dalam transaksi pinjaman uang (al-qard\}) yang diperhitungkan dari pokok pinjaman tanpa mempertimbangkan pemanfaatan dari/hasil pokok tersebut, berdasarkan tempo waktu, diperhitungkan secara pasti dimuka, dan pada umumnya berdasarkan persentase; 2) Riba adalah tambahan tanpa imbalan yang terjadi karena penangguhan dalam pembayaran yang diperjanjikan sebelumnya. Dan inilah yang disebut riba nasiah.

\footnotetext{
${ }^{12}$ Khaerul Umam, Manajemen Perbankan Syariah (Bandung: CV Pustaka Setia, 2013), 15.

${ }^{13}$ Muhamad, Manajemen Dana Bank Syariah (Jakarta: Rajawali Pers, 2015), 2.

${ }^{14}$ Khaerul Umam, Manajemen Perbankan Syariah, 16.

${ }^{15}$ Muhammad, Manajemen Bank Syariah, 76.

${ }^{16}$ Ibid., 77.
} 
Kedua, hukum bunga antara lain 1) Praktek pembungaan uang saat ini telah memenuhi kriteria riba yang terjadi pada zaman Rasulullah SAW, yakni riba nasiah. Dengan demikian, praktek pembungaan uang ini termasuk salah satu bentuk riba, dan riba haram hukumnya; 2) Praktek pembungaan tersebut hukumnya adalah haram, baik dilakukan oleh bank, asuransi, pasar modal, pegadaian, koperasi, dan keuangan lainnya, maupun dilakukan oleh individu.

Ketiga, bermuamalah dengan lembaga keuangan konvensional antara lain 1) Untuk wilayah yang sudah ada kantor/jaringan lembaga keuangan syariah dan mudah dijangkau, tidak dibolehkan melakukan transaksi yang didasarkan kepada perhitungan bunga; 2) Untuk wilayah yang belum ada kantor/jaringan lembaga keuangan syariah diperbolehkan melakukan kegiatan transaksi dilembaga keuangan konvensional berdasarkan prinsip darurat. ${ }^{17}$

Begitu juga dalam hadist Rasulullah SAW di jelaskan yang diriwayatkan oleh ABU Kuraid dan Washil ibn Abdul A'la bahwa Rasulullah SAW bersabda:

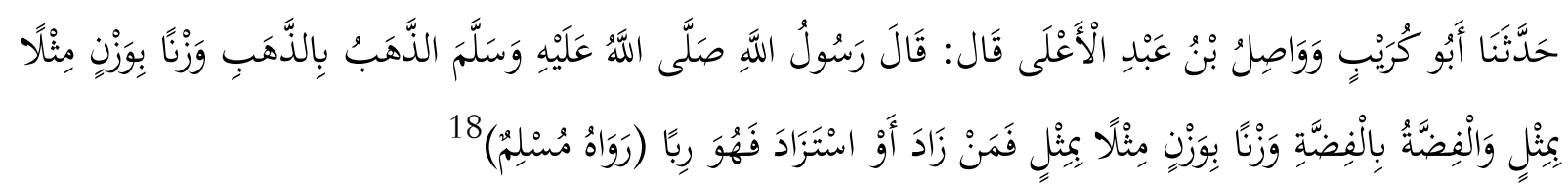

"Diriwayatkan oleh Abu Kuraib dan Washil bin Abdul A'la bahwa Rasulullah Shallallahu 'alaihi wa sallam bersabda, "Emas dengan emas harus sama dan sebanding, perak dengan perak harus sama dan sebanding. Barang siapa melebihkan atau menambah maka dia telah melakukan praktek riba." (HR. Muslim) ${ }^{19}$

Dari hadist tersebut dapat dipahami bahwa riba adalah ziyādah atau tambahan. Dalam istilah fikih, riba adalah pengambilan tambahan dari harta pokok sejarah bathil baik dalam transaksi jual beli maupun pinjam meminjam. ${ }^{20}$

Dasar pemikiran pembentukan bank syariah, yaitu bersumber dari larangan riba sebagaimana diterangkan dalam al-Quran:

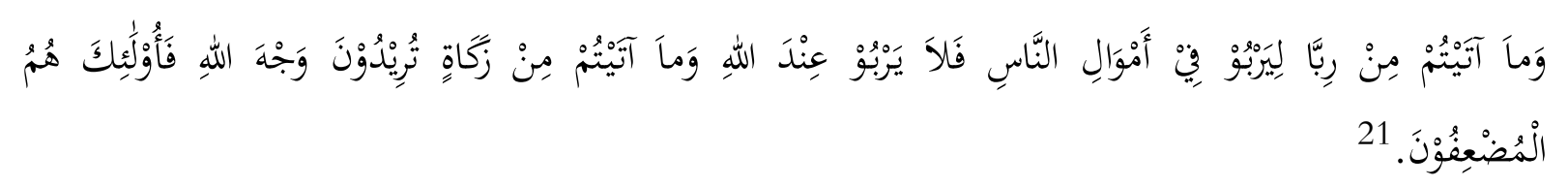

"Dan sesuatu riba (tambahan) yang kamu berikan agar dia bertambah pada harta manusia, Maka riba itu tidak menambah pada sisi Allah. dan apa yang kamu berikan berupa zakat yang kamu maksudkan untuk mencapai keridhaan Allah, maka (yang berbuat demikian) itulah orang-orang yang melipat gandakan (pahalanya)." ${ }^{22}$

\footnotetext{
17 Tim Pusat Komunikasi Ekonomi Syariah, Perbankan Syariah (Jakarta: PKES Publishing, 2008), 3.

${ }^{18}$ Muslim Ibn al-Hajjāj Abū al-Hasan al-Nisābūri, Shahih Muslim (Beirut: Dar al-Fikr), 692.

${ }^{19}$ Ilfi Nur Diana, Hadist-Hadist Ekonomi (Malang: Uin-Malang Press, 2008), 136.

${ }^{20}$ Ibid.

21 Al-Quran, 30:39.

${ }^{22}$ Kementerian Agama RI, Al-Quran dan Terjemahnya (Bandung: PT. Jabar Roudotul Jannah, 2010), 408.
} 
Adapun prinsip-prinsip perbankan syariah di antaranya:

1. Prinsip mudārabah adalah perjanjian atas suatu jenis kerja sama usaha di mana pihak pertama menyediakan dana dan pihak kedua bertanggung jawab atas pengelolaan usaha. ${ }^{23}$

2. Prinsip mushărakah yaitu perjanjian antara pihak-pihak untuk menyertakan modal dalam suatu kegiatan ekonomi dengan pembagian keuntungan atau kerugian sesuai nisbah yang disepakati. $^{24}$

3. Prinsip simpanan murni merupakan fasilitas yang diberikan oleh bank syariah untuk memberikan kesempatan kepada pihak yang kelebihan dana untuk menyimpan dananya dalam bentuk al- wadi' ah. ${ }^{25}$

4. Prinsip jual beli yaitu murābahah, adalah akad jual beli antara dua belah pihak yang di dalamnya, pembeli dan penjual menyepakati harga jual yang terdiri atas harga beli ditambah ongkos pembelian dan keuntungan bagi penjual. ${ }^{26}$

5. Prinsip kebajikan, yaitu penerimaan dan penyaluran dana kebajikan dalam bentuk zakat, infak, sedekah, dan lainnya serta penyaluran al-qarḍ al-ḥasan, yaitu penyaluran dan dalam bentuk pinjaman untuk tujuan menolong golongan miskin dengan penggunaan produktif tanpa diminta imbalan, kecuali pengembalian pokok utang. ${ }^{27}$

\section{Metode Penelitian}

Di dalam penelitian ini peneliti menggunakan penelitian kuantitatif dengan jenis eksplanatif, karena peneliti menjelaskan hubungan kausal antara variabel-variabel penelitian melalui pengujian hipotesis. Penelitian eksplanatif dimaksudkan untuk menjelaskan suatu generalisasi sampel terhadap populasinya atau menjelaskan hubungan, perbedaan atau pengaruh satu variabel dengan variabel lain. ${ }^{28}$ Berdasarkan hal itu peneliti menjelaskan Pengaruh Kelebihan Penghasilan dan Religiusitas Terhadap Intensi Masyarakat Desa Takeranklating Tikung Lamongan untuk Menjadi Nasabah di Perbankan Syariah, sehingga dengan maksud itu peneliti menggunakan penelitian kuantitatif jenis eksplanatif.

Sehingga dalam penelitian ini yang menjadi populasi sebagai objek penelitian adalah masyarakat Desa Takeranklating Kecamatan Tikung Kabupaten Lamongan. Sedangkan teknik pengambilan sampel yang digunakan di dalam penelitian ini yaitu purposive sampling. Purposive sampling adalah teknik penentuan sampel dengan pertimbangan tertentu. Di mana peneliti menentukan seseorang berhak menjadi sampel atau tidak berdasarkan tujuan yang ingin dicapai. Sementara untuk penentuan sampel peneliti menggunakan rumus Slovin sebagai berikut: ${ }^{29}$

\footnotetext{
${ }^{23}$ Rizal yaya, Akuntansi Perbankan Syariah (Jakarta: Salemba Empat, 2016), 53.

${ }^{24}$ Khaerul Umam, Manajemen Perbankan Syariah, 28.

${ }^{25}$ Muhammad, Manajemen Bank Syariah, 89.

${ }^{26}$ Khaerul Umam, Manajemen Perbankan Syariah, 28.

${ }^{27}$ Ibid., 28-30.

${ }^{28}$ Maman Rahman, Metode Penelitian Pendidikan Moral dalam Pendekatan Kuantitatif, Kualitatif, Campuran, Tindakan dan Pengembangan (Semarang: UNNES Press, 2011), 67.

${ }^{29}$ Syofian Siregar, Metode Penelitian Dilengkapi Dengan Perbandingan Perhitungan Manual \& SPSS (Jakarta: Prenadamedia Group, 2015), 34
} 


$$
n=\frac{\mathrm{N}}{1+N e^{2}}
$$

Keterangan :

$\mathrm{n}=$ jumlah sampel yang dicari

$\mathrm{N}=$ jumlah populasi

$\mathrm{e}=$ persen kelonggaran ketidaktelitian

Berdasarkan rumus tersebut peneliti dapat menentukan jumlah sampel yang digunakan sebanyak 91 orang dari 957 orang populasi dengan menggunakan rumus formula Slovin dan persen kelonggaran ketidaktelitian $10 \%$ atau 0.1 .

Penelitian ini menggunakan 3 (tiga) variabel yang terdiri dari 2 (dua) variabel independen dan 1 (satu) variabel dependen. Variabel independen yang peneliti gunakan yaitu kelebihan penghasilan dan religiusitas. Sementara variabel dependen yang digunakan yaitu intensi masyarakat Desa Takeranklating Kecamatan Tikung Kabupaten Lamongan untuk menjadi nasabah di perbankan syariah.

Data yang digunakan dalam penelitian ini adalah data primer dan data sekunder. Data primer adalah data yang berasal langsung dengan permasalahan yang diteliti, data ini diperoleh dari hasil kuesioner penelitian. ${ }^{30}$ Data primer yang peneliti gunakan adalah data dari hasil penyebaran angket kepada masyarakat yang mewakili masyarakat Desa Takeranklating sebagai sampel penelitian. Data sekunder adalah data yang tidak didapatkan secara langsung oleh peneliti tetapi diperoleh dari orang atau pihak lain. ${ }^{31}$ Data sekunder yang diperoleh yaitu dari dokumen tertulis yang peneliti anggap mendukung penelitian ini. Sedangkan sumber data yang digunakan adalah dari dokumen Kuesioner Pemutakhiran Data Indeks Desa Membangun Kabupaten Lamongan Tahun 2017.

Teknik pengumpulan data yang digunakan adalah kuisioner dan dokumentasi. Kuesioner merupakan teknik pengumpulan data yang dilakukan dengan cara memberi seperangkat pertanyaan atau pernyataan tertulis kepada responden untuk dijawabnya. Angket yang peneliti sebarkan menggunakan skala likert. Teknik dokumentasi merupakan teknik pengambilan data dari sumber-sumber tertentu yang dapat memberikan atau dapat melengkapi data primer yang didapatkan dari hasil angket yang peneliti sebarkan.

Di dalam penelitian ini, peneliti melakukan uji vailiditas dan reliabilitasnya. Validitas adalah untuk mengukur apa yang semestinya diukur. Artinya instrument yang valid berarti alat ukur yang digunakan untuk mendapatkan data itu valid. Valid berarti instrument tersebut dapat digunakan untuk mengukur apa yang seharusnya diukur. ${ }^{32}$ Sedangkan uji realibilitas adalah instrument yang bila digunakan beberapa kali untuk mengukur obyek yang sama akan menghasilkan data yang sama.

Teknik analisis data yang digunakan adalah uji regresi linier berganda yang meliputi uji t dan uji f. Pada uji parsial ini dilakukan pengujian seberapa besar pengaruh masing-masing

\footnotetext{
${ }^{30}$ Julia Sri Ningsih, "Pengaruh Persepsi, Tingkat Religiusitas dan Disposable Income Terhadap Minat Menabung di Perbankan Syari’ah” (Skripsi--UIN Raden Intan Lampung, 2017), 56.

${ }^{31}$ Ibid.

${ }^{32}$ Sugiyono, Metode Penelitian Pendidikan Pendekatan Kuantitatif, Kualitatif, dan R\&D (Bandung: Alfabeta, 2008), 173.
} 
variabel bebas secara parsial mempunyai pengaruh yang signifikan pada kerangka konseptual. Sedangkan Pada uji simultan dilakukan pengujian terhadap variabel bebas dengan secara bersama-sama terhadap variabel terikat.

\section{Uji Validitas}

Dalam penelitian ini uji validitas dikatakan valid jika tingkat signifikansinya dibawah 0,05. Jika $\mathrm{r}$ hitung $>\mathrm{r}$ tabel maka dapat dikatakan valid. Berdasarkan hasil uji validitas instrumen dapat ditampilkan sebagai berikut:

Tabel 1.1

Hasil Uji Validitas Kelebihan Penghasilan

\begin{tabular}{|l|c|c|c|}
\hline \multicolumn{1}{|c|}{ Pernyataan } & r hitung & r tabel & Keterangan \\
\hline Pernyataan item 1 & 0,732 & 0,2061 & valid \\
\hline Pernyataan item 2 & 0,793 & 0,2061 & valid \\
\hline Pernyataan item 3 & 0,737 & 0,2061 & valid \\
\hline Pernyataan item 4 & 0,743 & 0,2061 & valid \\
\hline Pernyataan item 5 & 0,856 & 0,2061 & valid \\
\hline Pernyataan item 6 & 0,696 & 0,2061 & valid \\
\hline Pernyataan item 7 & 0,698 & 0,2061 & valid \\
\hline Pernyataan item 8 & 0,783 & 0,2061 & valid \\
\hline Pernyataan item 9 & 0,690 & 0,2061 & valid \\
\hline Pernyataan item 10 & 0,702 & 0,2061 & valid \\
\hline Pernyataan item 11 & 0,911 & 0,2061 & valid \\
\hline Pernyataan item 12 & 0,676 & 0,2061 & valid \\
\hline Pernyataan item 13 & 0,807 & 0,2061 & valid \\
\hline Pernyataan item 14 & 0,779 & 0,2061 & valid \\
\hline Pernyataan item 15 & 0,687 & 0,2061 & valid \\
\hline Pernyataan item 16 & 0,886 & 0,2061 & valid \\
\hline Pernyataan item 17 & 0,659 & 0,2061 & valid \\
\hline Pernyataan item 18 & 0,905 & 0,2061 & valid \\
\hline
\end{tabular}

Sumber: Data diolah menggunakan SPSS 20

Hasil uji instrumen dalam tabel 1.1 menunjukkan setiap item dalam uji validitas tersebut adalah valid, karena $\mathrm{r}$ hitung $>\mathrm{r}$ tabel.

Tabel 1.2

Hasil Uji Validitas Variabel Religiusitas

\begin{tabular}{|l|c|c|c|}
\hline \multicolumn{1}{|c|}{ Pernyataan } & r hitung & r tabel & Keterangan \\
\hline Pernyataan item 1 & 0,709 & 0,2061 & valid \\
\hline Pernyataan item 2 & 0,832 & 0,2061 & valid \\
\hline Pernyataan item 3 & 0,609 & 0,2061 & valid \\
\hline Pernyataan item 4 & 0,586 & 0,2061 & valid \\
\hline Pernyataan item 5 & 0,906 & 0,2061 & valid \\
\hline Pernyataan item 6 & 0,609 & 0,2061 & valid \\
\hline
\end{tabular}




\begin{tabular}{|l|c|c|c|}
\hline Pernyataan item 7 & 0,849 & 0,2061 & valid \\
\hline Pernyataan item 8 & 0,842 & 0,2061 & valid \\
\hline Pernyataan item 9 & 0,775 & 0,2061 & valid \\
\hline Pernyataan item 10 & 0,791 & 0,2061 & valid \\
\hline Pernyataan item 11 & 0,764 & 0,2061 & valid \\
\hline Pernyataan item 12 & 0,816 & 0,2061 & valid \\
\hline Pernyataan item 13 & 0,893 & 0,2061 & valid \\
\hline Pernyataan item 14 & 0,888 & 0,2061 & valid \\
\hline Pernyataan item 15 & 0,806 & 0,2061 & valid \\
\hline Pernyataan item 16 & 0,780 & 0,2061 & valid \\
\hline Pernyataan item 17 & 0,877 & 0,2061 & valid \\
\hline Pernyataan item 18 & 0,771 & 0,2061 & valid \\
\hline
\end{tabular}

Sumber: Data diolah menggunakan SPSS 20

Berdasarkan hasil uji instrumen dalam tabel 1.2 semua item pernyataan pada variabel religiusitas (X2) dalam uji validitas dikatakan valid, karena $r$ hitung $>r$ tabel.

Tabel 1.3

Hasil Uji Validitas Intensi Masyarakat

\begin{tabular}{|l|c|c|c|}
\hline \multicolumn{1}{|c|}{ Pernyataan } & r hitung & r tabel & Keterangan \\
\hline Pernyataan item 1 & 0,754 & 0,2061 & valid \\
\hline Pernyataan item 2 & 0,824 & 0,2061 & valid \\
\hline Pernyataan item 3 & 0,773 & 0,2061 & valid \\
\hline Pernyataan item 4 & 0,940 & 0,2061 & valid \\
\hline Pernyataan item 5 & 0,921 & 0,2061 & valid \\
\hline Pernyataan item 6 & 0,764 & 0,2061 & valid \\
\hline Pernyataan item 7 & 0,940 & 0,2061 & valid \\
\hline Pernyataan item 8 & 0,921 & 0,2061 & valid \\
\hline Pernyataan item 9 & 0,940 & 0,2061 & valid \\
\hline Pernyataan item 10 & 0,921 & 0,2061 & valid \\
\hline Pernyataan item 11 & 0,764 & 0,2061 & valid \\
\hline
\end{tabular}

Sumber: Data diolah menggunakan SPSS 20

Berdasarkan hasil uji instrumen yang terdapat dalam tabel 1.3 di atas setiap item yang digunakan dalam uji validitas tersebut adalah valid, karena berdasarkan hasil uji tersebut bahwa semua item pernyataan pada variabel intensi masyarakat (Y) dikatakan valid, karena $\mathrm{r}$ hitung > r tabel.

\section{Uji Reliabilitas}

Berdasarkan hasil uji reliabilitas dengan menggunakan program SPSS dapat ditampilkan sebagai berikut: 
Tabel 1.4

Hasil Uji Reliabilitas

\begin{tabular}{|l|l|l|l|}
\hline \multicolumn{1}{|c|}{ Variabel } & \multicolumn{1}{|c|}{$\begin{array}{c}\text { Reliability } \\
\text { coefficients }\end{array}$} & $\begin{array}{c}\text { Cronbach's } \\
\text { Alpha }\end{array}$ & \multicolumn{1}{|c|}{ Keterangan } \\
\hline Kelebihan penghasilan & 18 item & 0,958 & Reliabel \\
\hline Religiusitas & 18 item & 0,964 & Reliabel \\
\hline Intensi masyarakat & 11 item & 0,966 & Reliabel \\
\hline
\end{tabular}

Sumber: Data diolah menggunakan SPSS 20

Berdasarkan tabel 1.4 tersebut bahwa hasil uji Reliabilitas menunjukkan tingkat reliabilitas setiap item instrumen yang digunakan dalam penelitian ini adalah $>0,60$ maka istrumen tersebut dinyatakan reliabel. Maka dengan begitu instrumen yang digunakan dapat digunakan atau dapat dipercaya.

\section{Uji Regresi Linier Berganda}

Analisis regresi linier berganda yang peneliti gunakan dalam penelitian ini dimaksudkan untuk mengetahui pengaruh variabel independent (kelebihan penghasilan dan religiusitas) terhadap variabel dependent (intensi masyarakat). Pengaruh yang dimaksud antara variabel independent terhadap variabel dependent secara parsial maupun secara simultan dengan begitu peneliti mengetahui pengaruh variabel independent secara parsial terhadap variabel dependent, begitu juga peneliti mengetahui pengaruh variabel independent secara simultan (bersama sama) mempengaruhi variabel dependent.

Tabel 1.6

Hasil Uji Regresi Berganda

Coefficients $^{\mathrm{a}}$

\begin{tabular}{|l|r|r|r|r|r|}
\hline \multirow{2}{*}{ Model } & \multicolumn{2}{|c|}{$\begin{array}{c}\text { Unstandardized } \\
\text { Coefficients }\end{array}$} & $\begin{array}{r}\text { Standardized } \\
\text { Coefficients }\end{array}$ & \multirow{2}{*}{$\mathrm{t}$} & \multirow{2}{*}{ Sig. } \\
\cline { 2 - 5 } & \multicolumn{1}{c|}{$\mathrm{B}$} & \multicolumn{1}{c|}{ Std. Error } & \multicolumn{1}{c|}{ Beta } & & \\
\hline 1 (Constant) & -2.333 & .928 & & -2.513 & .014 \\
Kelebihan penghasilan & .022 & .010 & .028 & 2.105 & .038 \\
(X1) & .622 & .008 & .996 & 75.635 & .000 \\
Religiusitas (X2) & & & & & \\
\hline
\end{tabular}

a. Dependent Variable: Intensi masyarakat (Y)

Dari hasil analisis dapat diketahui persamaan linier berganda sebagai berikut $\mathrm{Y}=-2,333$ $+0,022(\mathrm{X} 1)+0,622(\mathrm{X} 2)$.

Berdasarkan hasil analisis regresi berganda tersebut terdapat persamaan yang menggambarkan koefisien regresi dari kedua variabel bebas bertanda positif hal tersebut dapat diartikan bahwa apabila kedua variabel bebas (b1 dan b2) yaitu kelebihan penghasilan dan religiusitas terpenuhi. Ini menunjukkan bahwa intensi masyarakat untuk menjadi nasabah di perbankan syariah meningkat. 


\section{Uji Parsial (Uji T)}

Uji parsial (Uji T) yang peneliti gunakan untuk menunjukkan adanya pengaruh atau tidak variabel bebas secara parsial terhadap variabel terikat.

Tabel 1.7

Hasil Uji Parsial (Uji T)

\begin{tabular}{|l|l|l|l|l|}
\hline \multicolumn{1}{|c|}{ Variabel } & \multicolumn{1}{c|}{ t hitung } & \multicolumn{1}{c|}{ t tabel } & Signifikan & \multicolumn{1}{c|}{ Keterangan } \\
\hline Kelebihan penghasilan & 2.105 & 1,991 & 0,038 & Signifikan \\
\hline Religiusitas & 75.635 & 1,991 & 0,000 & Signifikan \\
\hline
\end{tabular}

Sumber: Data diolah menggunakan SPSS 20

Berdasarkan tabel 1.7 hasil uji parsial (Uji T) dapat dijelaskan sebagai berikut:

1. Variabel kelebihan penghasilan (X1) dengan melihat hasil nilai t hitung sebesar 2,105 dengan nilai tingkat signifikansinya $0,038<0,05$ maka dapat dinyatakan menolak Ho dan menerima Ha. Begitu halnya juga dengan melihat perhitungan dan membandingkan antara nilai $\mathrm{t}$ hitung dengan $\mathrm{t}$ tabelnya dengan taraf signifikansi 5\% dapat dikatakan bahwa t hitung 2,105 > t tabel 1,991 dengan begitu ho ditolak dan menerima ha.

2. Variabel religiusitas (X2) dengan melihat hasil perhitungan dengan menggunakan program spss nilai t hitung sebesar 75,635 dengan nilai tingkat signifikansinya 0,000 < 0,05 maka dapat dinyatakan menolak Ho dan menerima Ha. Begitu halnya juga dengan melihat perhitungan dan membandingkan antara nilai $t$ hitung dengan $t$ tabelnya dengan taraf signifikansi 5\% dapat dikatakan bahwa t hitung 75,635 > t tabel 1,991 dengan begitu ho ditolak dan menerima ha.

\section{Uji F}

Uji $F$ yang peneliti gunakan untuk mengetahui variabel independent dalam hal ini variabel kelebihan penghasilan (X1) dan variabel religiusitas (X2) secara simultan (bersamasama) mempengaruhi atau tidak mempengaruhi terhadap variabel dependent intensi masyarakat (Y).

Tabel 1.8

Hasil Uji F

ANOVA $^{\text {b }}$

\begin{tabular}{|l|r|r|r|r|r|}
\hline \multicolumn{1}{|c|}{ Model } & \multicolumn{1}{c|}{$\begin{array}{c}\text { Sum of } \\
\text { Squares }\end{array}$} & df & Mean Square & F & \multicolumn{1}{c|}{ Sig. } \\
\hline 1Regression & 2059.268 & 2 & 1029.634 & 2906.753 & .000 \\
Residual & 31.171 & 88 & .354 & & \\
Total & 2090.440 & 90 & & & \\
\hline
\end{tabular}

a. Predictors: (Constant), Religiusitas (X2), Kelebihan penghasilan (X1)

b. Dependent Variable: Intensi masyarakat (Y) 
Berdasarkan tabel 1.8 hasil uji $\mathrm{F}$ di atas dapat dijelaskan bahwa apabila dilihat nilai signifikasinya adalah sebesar 0,000 $<0,05$ maka dapat dinyatakan bahwa Ho ditolak dan menerima Ha. Dan berdasarkan nilai f hitung 2906,753 > f tabel 3,10 maka dapat dijelaskan bahwa ho ditolak dan ha diterima.

\section{Hasil Penelitian}

1. Pengaruh kelebihan penghasilan terhadap intensi masyarakat Desa Takeranklating untuk menjadi nasabah di perbankan syariah.

Berdasarkan hasil hipotesis yang telah peneliti susun bahwa nilai variabel kelebihan penghasilan sebesar 0,038 $<0,05$ sehingga dapat disimpulkan Ho ditolak dan Ha diterima. Dengan begitu kelebihan penghasilan berpengaruh positif terhadap intensi masyarakat Desa Takeranklating untuk menjadi nasabah di perbankan syariah.

Begitu halnya juga apabila melihat dari hasil t hitung dangan t tabel sangat jelas terlihat bahwa t hitung 2,105 > t tabel 1,991. Maka dapat disimpulkan bahwa kelebihan penghasilan berpengaruh terhadap intensi masyarakat Desa Takeranklating untuk menjadi nasabah di perbankan syariah.

2. Pengaruh religiusitas terhadap intensi masyarakat Desa Takeranklating untuk menjadi nasabah di perbankan syariah.

Pada variabel religiusitas nilai signifikansinya adalah sebesar 0,000 , sementara nilai signifikansi yang digunakan adalah 0,05 . Dengan begitu nilai signifikansi $0,000<0,05$, maka Ho ditolak dan menerima Ha. Sehingga terdapat pengaruh religiusitas terhadap intensi masyarakat Desa Takeranklating untuk menjadi nasabah di perbankan syariah. Begitu juga apabila melihat tingkat atau nilai t hitung yang terdapat dalam hasil uji $\mathrm{T}$ tersebut sebesar 75,635, sedangkan nilai t tabel sebesar 1,991 atau disingkat dengan $t$ hitung > t tabel, maka Ho ditolak Ha diterima. Sehingga peneliti simpulkan bahwa terdapat pengaruh religiusitas terhadap intensi masyarakat Desa Takeranklating untuk menjadi nasabah di perbankan syariah.

3. Pengaruh kelebihan penghasilan dan religiusitas secara bersama-sama terhadap intensi masyarakat Desa Takeranklating untuk menjadi nasabah di perbankan syariah.

Berdasarkan hasil uji $\mathrm{F}$ yang peneliti lakukan terlihat bahwa nilai signifikansi $\mathrm{F}$ sebesar 0,000 dan nilai f hitung sebesar 2906.753. Sementara disisi lain dapat dilihat bahwa tingkat signifikansi yang digunakan adalah sebesar 0,05 atau 5\% dan $\mathrm{f}$ tabel yang digunakan sebesar 3,10. Dari itu dapat di jelaskan bahwa tingkat signifikansinya adalah $0,000<0,05$. Begitu juga apabila melihat nilai $\mathrm{f}$ hitung dan $\mathrm{f}$ tabelnya yaitu $\mathrm{f}$ hitung 2906,753 > f tabel 3,10. Maka dapat disimpulkan bahwa Ho ditolak dan Ha diterima, sehingga pengaruh kelebihan penghasilan dan religiusitas berpengaruh positif terhadap intensi masyarakat Desa Takeranklating untuk menjadi nasabah di perbankan syariah.

\section{Kesimpulan}

Berdasarkan pengolahan data dengan menggunakan uji regresi linier berganda dan setelah dilakukan analisis data dengan melihat hasil pengujian hipotesis maka dapat ditarik beberapa kesimpulan sebagai berikut: 
1. Variabel kelebihan penghasilan berpengaruh positif terhadap intensi masyarakat Desa Takeranklating untuk menjadi nasabah di perbankan syariah, hal tersebut dapat dilihat berdasarkan hasil perhitungan uji $\mathrm{T}$. Dengan nilai signifikansinya $0,038<0,05$ dapat disimpulkan bahwa Ho ditolak dan menerima Ha atau dengan kata lain kelebihan penghasilan berpengaruh signifikan terhadap intensi masyarakat Desa Takeranklating untuk menjadi nasabah di perbankan syariah.

2. Variabel religiusitas berpengaruh signifikan terhadap intensi masyarakat Desa Takeranklating untuk menjadi nasabah di perbankan syariah. Hal ini dapat dijelaskan hasil perhitungan uji T yaitu nilai signifikansi $0,000<0,05$. Dapat disimpulkan bahwa Ho ditolak dan menerima $\mathrm{Ha}$ atau dengan kata lain religiusitas berpengaruh signifikan terhadap intensi masyarakat Desa Takeranklating untuk menjadi nasabah di perbankan syariah.

3. Variabel kelebihan penghasilan dan religiusitas secara bersama-sama berpengaruh signifikan terhadap intensi masyarakat Desa Takeranklating untuk menjadi nasabah di perbankan syariah. Hal ini dapat dilihat dari hasil perhitungan uji $\mathrm{F}$ yaitu nilai sigfikansi $0,000<0,05$ sehingga dapat disimpulkan bahwa Ho ditolak dan menerima $\mathrm{Ha}$ atau dengan kata lain kelebihan penghasilan dan religiusitas secara bersama-sama berpengaruh signifikan terhadap intensi masyarakat Desa Takeranklating untuk menjadi nasabah di perbankan syariah.

\section{Daftar Rujukan}

Alma, Buchari. Manajemen Pemasaran dan Pemasaran Jasa. Bandung: Alfabeta, 2009.

Diana, Ilfi Nur. Hadist-Hadist Ekonomi. Malang: Uin-Malang Press, 2008.

Hunafa. "Etika Konsumsi dalam Prespektif Ekonomi Islam" dalam Jurnal Studi Islamika. Vol. 11, No. 2, Desember, 2014.

Ibn al-Hajjāj Abū al-Ḥasan al-Nisābūri, Muslim. Ṣahịḥ al-Muslim. Beirut: Dar al-Fikr, 1354 $\mathrm{H} / 1935 \mathrm{M}$.

Kementerian Agama RI. Al-Quran dan Terjemahnya. Bandung: PT. Jabar Roudotul Jannah, 2010.

Muhammad. Manajemen Bank Syariah. Yogyakarta: STIM YKPN, 2011. . Manajemen Bank Syariah. Yogyakarta: STIM YKPN, 2015.

Ningsih, Julia Sri. "Pengaruh Persepsi, Tingkat Religiusitas dan Disposable Income Terhadap Minat Menabung di Perbankan Syari'ah.” Skripsi--UIN Raden Intan Lampung, 2017.

Peter, J Paul dan Jerry C. Olson. Perilaku Konsumen dan Strategi Pemasaran. Jakarta: Salemba Empat, 2014.

Prasetijo, Ristiyanti dan John J.O.I Ihalauw. Perilaku Konsumen (Yogyakarta: Andi Offset, 2009.

Rahman, Maman. Metode Penelitian Pendidikan Moral dalam Pendekatan Kuantitatif, Kualitatif, Campuran, Tindakan dan Pengembangan. Semarang: UNNES Press, 2011.

Reza, Iredho Fani. "Hubungan antara religiusitas dengan moralitas pada remaja di madrasah aliyah (MA) UIN Syarif Hidayatullah" dalam Jurnal Humanitis. Vol. X No. 2, Agustus, 2013.

Sangabdji, Etta Mamang dan Sopiah. Perilaku Konsumen. Yogyakarta: Andi Offset, 2013. 
Siregar, Syofian. Metode Penelitian Dilengkapi Dengan Perbandingan Perhitungan Manual \& SPSS. Jakarta: Prenadamedia Group, 2015.

Sugiyono. Metode Penelitian Pendidikan Pendekatan Kuantitatif, Kualitatif, dan R\&D. Bandung: Alfabeta 2008.

Tim Pusat Komunikasi Ekonomi Syariah. Perbankan Syariah. Jakarta: PKES Publishing, 2008.

Umam, Khaerul. Manajemen Perbankan Syariah. Bandung: CV Pustaka Setia, 2013.

Yaya, Rizal. Akuntasi Perbankan Syariah. Jakarta: Salemba Empat, 2016. 